\title{
BUSINESS
}

\section{Promise boiling over}

\section{Geothermal power is one of the hottest prospects in the burgeoning clean-energy market. But, as Kurt Kleiner reports, it's not close enough to home for many uses.}

celand is famously rich in geothermal energy. The country sits on a geological hot spot that provides enough power to generate one-quarter of its electricity and heat $90 \%$ of its homes.

Now, the Icelandic bank Glitnir has decided that the time is ripe to take advantage of geothermal opportunities elsewhere. In September, the bank opened an office in New York to pursue what it boldly predicts will be $\$ 40$ billion worth of geothermal investment in the United States over the next 20 or so years.

Glitnir's move is one of a growing number of signs that geothermal energy is ready to become a more significant player in world energy production. "If you're a utility, your first choice of renewable energy is geothermal," says Thomas King, managing director of the US Renewables Group investment fund in New York. "It's the cream of the crop."

King's bullishness reflects a growing belief among energy analysts that although the technology hasn't received as much attention as wave or solar power, geothermal companies have outstanding long-term potential. Robert Wilder, chief executive of Californian cleanenergy consultancy WilderShares, points to Ormat Technologies, a maker of geothermal plants based in Reno, Nevada, as a sign of the trend: its share price has risen from about $\$ 16$ a share in April 2005 to $\$ 50$ this week.

Nevertheless, with just 9 gigawatts or so of installed capacity, geothermal energy accounts for only about $0.2 \%$ of all electricity produced around the world. In theory, geothermal heat can be found anywhere in the world if you dig deep enough. But in practice, it has only been worth harnessing in regions where water is found

"A well-managed reservoir can keep going practically forever." in combination with hot, porous rock close to the surface.

For instance, just north of San Francisco, a geothermal field called The Geysers generates 760 megawatts of electric power. The plants there take advantage of a large, naturally occurring underground steam reservoir that can be tapped by drilling relatively shallow wells.

The Geysers are examples of 'dry-steam' power plants: the steam that comes out of the reservoir contains little or no liquid water, and can therefore be routed directly to a turbine to create electricity. However, most plants are of the 'flash-steam' variety. These plants use water that has been heated to about $180{ }^{\circ} \mathrm{C}$, but remains liquid because it is highly pressurized underground. The water is then pumped to the surface. Because the pressure there is lower, most of the water 'flashes' into steam, which can be used to operate a turbine.

When the water is around $100-180^{\circ} \mathrm{C}$, 'binary' plants are used. These make use of hot water to heat a working fluid, such as isobutane, which has a lower boiling point than water does. The vaporized working fluid is then used to drive the turbine.

\section{Deep pockets}

Even in favourable geological locations, geothermal power has a high capital cost, mainly because it costs a lot to dig the wells. Balancing that are its low fuel costs. Overall, conventional geothermal plants in the United States deliver electricity for between 5 cents and 8 cents per kilowatt-hour: not much more than the average of 4 cents per kilowatt-hour for electricity from a coal-fired power plant.

In Australia, a firm called Geodynamics is trying to develop a new technique that can take advantage of geothermal energy in the absence of a ready-formed reservoir of water.

"We believe that our area is probably the best location in the world to make this approach economically viable," says Doone Wyborn, a founder and executive director of Geodynamics in Queensland.

The firm plans to use the Cooper Basin, a geological feature of the Australian interior, in which rocks with a temperature of about $270{ }^{\circ} \mathrm{C}$ are available quite close to the surface.

Geodynamics aims to drill two wells to a depth of 4.3 kilometres, and to fracture the hot granite in the rocks by pumping down cold water. Once the rock is permeable enough, the system will act as a heat exchanger - water will be pumped down one well, migrate through the rock to the other well, from which it will be extracted and used to generate electricity.

The company plans to have a 50-megawatt

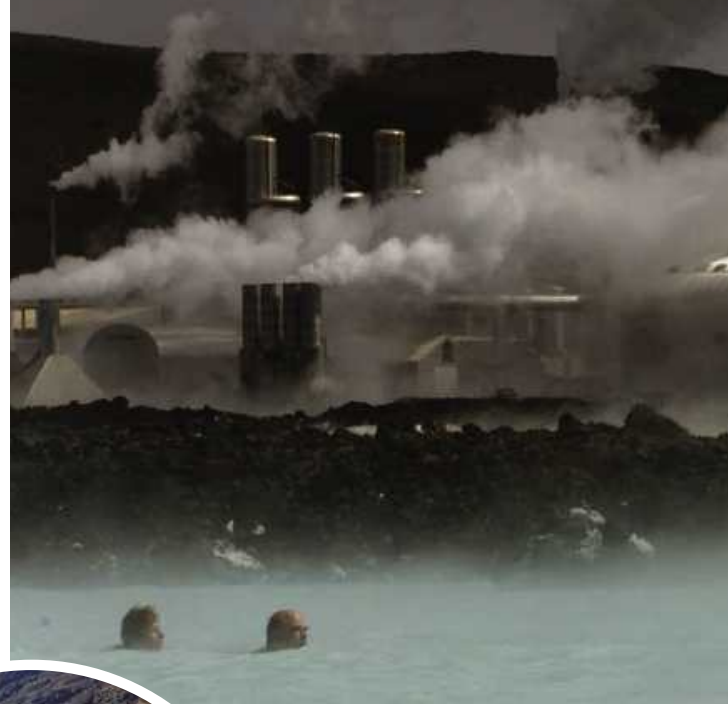

एक्ष

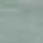

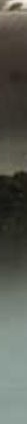

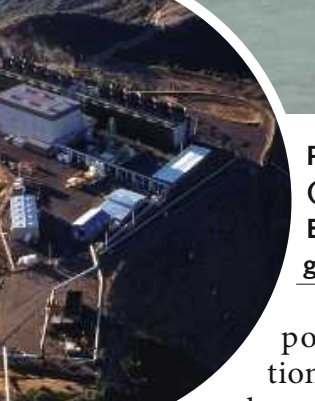
Cooper Basin at 10,000 megawatts of power, which could be realized by drilling hundreds of wells.

The Geodynamics project is an example of a technology called 'hot-dry-rock' or 'hotfractured-rock' geothermal. A report by the Massachusetts Institute of Technology (MIT) in Cambridge published in January concluded that this type of 'enhanced' geothermal power generation could greatly enhance our ability to tap geothermal energy. "I feel it's been an ignored option," says Jefferson Tester, the chemical engineer at MIT who headed the panel that wrote the report, The Future of Geothermal Energy. "But I'm very optimistic about the possibility if a lot of things come into place."

Eventually, geothermal energy could be available almost everywhere, the report contends. Deep drilling from any location will eventually hit hot rock. In the United States alone, the report says, the amount of energy available by drilling up to 10 kilometres below the surface is a stunning 13 yottajoules $\left(10^{24}\right.$ joules), or 130,000 times the annual energy consumption of the entire country.

Only a fraction of that is economical to 


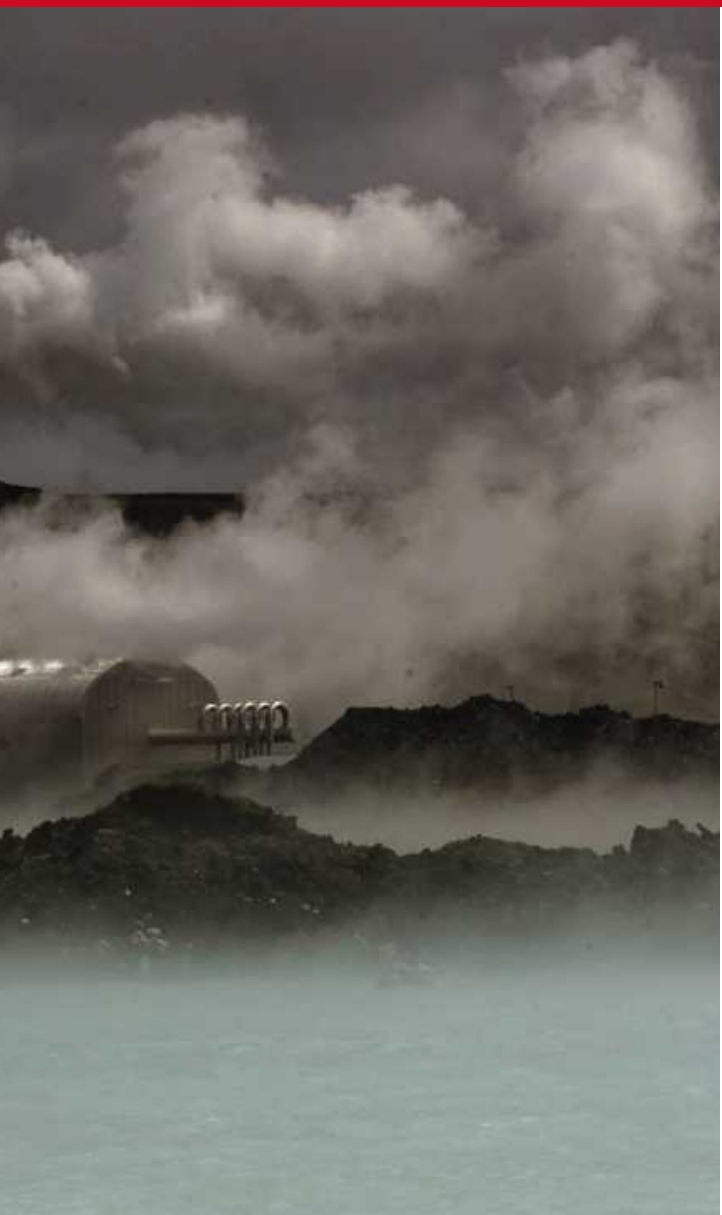

exploit. Even so, the report concluded, in the United States alone, enhanced geothermal electrical capacity could reach 100 gigawatts in the next 50 years - enough to fill about $10 \%$ of the country's electricity needs.

An important benefit of such systems is their flexibility, Tester says. They could prove to be economical from a very large scale, all the way down to a relatively small, 1-megawatt plant that also provides direct heating to buildings. As in Iceland, this combined heat-and-power approach greatly enhances the economics of geothermal power. But it requires building communities that can make use of the heat.

\section{Powerful exchanges}

Another geothermal option is the use of heat pumps. These use a vapour-compression cycle - the same principle that makes a refrigerator work - to transfer heat from below the ground in the winter, and to transfer excess heat out from buildings in the summer.

Tester says that geothermal power will make economic sense even without special incentives or restrictions on carbon emissions. As governments move to restrict greenhouse-gas emissions, geothermal power is set to look even better.

King adds that the standards for renewable energy being set by individual states have kicked off a flurry of interest in geothermal power. "It's clean, it's close to zero emissions, and it's baseload power that runs 24 hours a day, 7 days a week. And a well-managed reservoir can keep going practically forever," he says.

\section{IN BRIEF}

EURO TIE-UP Swiss drug giant Novartis has extended its partnership with MorphoSys, a German biotechnology firm, saying it will pay at least US $\$ 600$ million over 10 years as the price of working with the smaller company to help it discover and develop antibody-based medicines. If Munich-based MorphoSys meets milestones for clinical development and market approval, the payments could exceed \$1 billion, the companies said on 2 December. Novartis will gain almost exclusive access to the smaller firm's libraries of human antibodies, copies of which will be transferred to Novartis research sites.

MUTUAL MOUSE Sanofi-Aventis has struck a deal with US biotech firm Regeneron Pharmaceuticals to discover and develop therapies with a genetically engineered 'super-mouse' that can make human antibodies. Under a deal announced on 29 November, the Paris-based drugmaker will pay Regeneron, based in Tarrytown, New York, $\$ 85$ million up front, and up to $\$ 475$ million in research and development costs over the next 5 years. Sanofi will buy $\$ 312$ million of stock in the smaller firm, boosting its stake from $4 \%$ to $19 \%$.

NO APPROVAL An advisory panel to the US Food and Drug Administration has ruled that the cancer drug Avastin (bevacizumab) should not be approved for the treatment of advanced breast cancer. Shares in Genentech, the California-based biotechnology company that makes the drug, fell by $\$ 10$ to $\$ 66$ as news of the decision emerged last week. European regulators approved the drug for breast cancer use earlier in the year, but the FDA panel heard that although the drug helped some patients there was insufficient evidence that it improved their long-term survival prospects, and voted 5-4 against its approval.

\section{MARKET WATCH}

\section{CLEAN-ENERGY STOCKS}

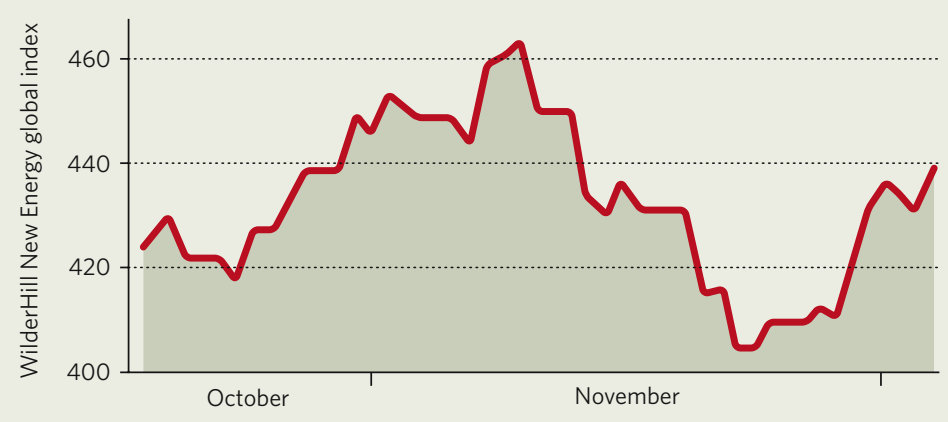

The inexorable rise of global renewable energy stocks - as measured by the WilderHill New Energy Global Innovation Index (symbol NEX on the US stock exchange) juddered to a halt last month. Specialists attribute the reverse to doubts about pending US energy legislation as well as to the global credit crunch, which has hit stock markets in general.

The US Congress is currently considering an energy bill that will provide tax credits for renewable energy. But growing doubts about the extent of the subsidies have worried investors who had hoped that the bill would spur demand for wind and solar-power equipment, says Robert Wilder, founder of WilderShares, a Californian consultancy that co-compiles the index with New Energy Finance of London. He adds that biofuels stocks have "crashed and burned" as doubts grow about the commercial usefulness of the technology.

However it is concern about the availability of credit in the economy that has hit shares hardest, says Michael Leibreich, founder of New Energy Finance. He says that the market has been on "a bit of a roller-coaster ride", but notes that when all is said and done, it is still up $50 \%$ since the start of the year. "This reflects the extraordinary level of interest in the sector, evidenced by the continuing wave of money washing into it," he says.

A huge initial public offering planned for 13 December by lberdrola Renewables, the renewables arm of Madrid-based utility Iberdrola, could raise up to $€ 6$ billion (US\$8.8 billion), reminding the markets of this strength, Leibreich says.

Colin Macilwain 